\title{
Concurrent Echinococcus Disease with Colorectal Carcinoma: Reports of Two Cases
}

\author{
Eş Zamanlı Kolorektal Karsinom ve Ekinokok Hastalığı: İki Olgu Sunumu
}

Kemal Peker ${ }^{1}$, Abdullah Inal

'Department of General Surgery, Faculty of Medicine, Erzincan University, Erzincan, Turkey

${ }^{2}$ Clinic of General Surgery, Mengücek Gazi Education and Research Hospital, Erzincan, Turkey

\begin{abstract}
Colorectal cancer (CRC) is currently the most common malignity of the gastrointestinal (GI) system in the world. CRC is the third most frequently diagnosed cancer in the U.S.A and it ranks third in cancer-related causes of death. Its etiology is complex, involving both environmental and genetic factors. Hydatid disease is an endemic disease, especially in eastern countries. E. granulosus and E. multilocularis are the most frequent types responsible for hydatidosis in human beings. Echinococcus larvae develop in cystic form, mostly in the liver or lungs. We presented two cases of rectum cancer who had co-existing liver echinococcus. (JAREM 2013; 3: 123-5)
\end{abstract}

Key Words: Colorectal cancer, echinococcus, hydatid disease

\section{ÖZET}

Kolorektal Kanserler (KRK), günümüz dünyasında en sık görülen gastrointestinal sistem (GI) tümörleridir. Amerika Birleşik Devletlerinde tanısı üçüncü sıklıkta konulan tümörler olup aynı zamanda üçüncü sıklıkta ölüm nedenidirler. Etyolojisi karmaşık olup çevresel ve genetik faktörler suçlanmaktadır. Ekinokok hastalığı özellikle doğu ülkelerinde görülen endemik bir hastalıktır. E. granülozis ve E. multilokülaris insanlarda en sık hastalık yapan parazitlerdir. Ekinokok larvaları çoğunlukla karaciğer ve akciğerlerde kistik formda gelişmektedirler. Çalışmamızda rektum karsinomuna eşlik eden iki ekinokok vakası sunduk. (JAREM 2013; 3: 123-5)

Anahtar Sözcükler: Kolorektal kanser, ekinokok, hidatik hastalık

\section{INTRODUCTION}

Colorectal cancer (CRC) is predominantly a disease of developed countries, indicating a risk for components of the western lifestyle. A huge body of evidence has implicated modifiable lifestyle factors, including smoking, physical activity, body composition, alcohol intake, and diet, in the etiology of colorectal cancer. However, no single component seems likely to explain the large international variation in colorectal cancer incidence (1). In the United States, colorectal cancer is the most frequently diagnosed cancer in both men and women, and also is the third leading cause of cancer-related deaths. Still, colorectal cancer can be considered preventable with screening and early diagnosis (2).

Echinococcosis is a zoonosis caused by adult or larval stages of cestodes belonging to the genus Echinococcus. Larval infection is characterized by long term growth of metacestode (hydatid) cysts in the intermediate host. The two major species of public health importance are E. granulosus and E. multilocularis, which cause cystic echinococcosis (CE) and alveolar echinococcosis $(\mathrm{AE})$, respectively. These are life-threatening diseases, and they have a poor prognosis unless appropriate clinical management is carried out (3).

Although both colorectal carcinomas and hydatid disease are relatively frequent diseases, especially in eastern countries, there are very few reports of synchronous occurence of the two conditions. We present two rectal cancer cases with concurrent hepatic

Address for Correspondence / Yazışma Adresi: Dr. Kemal Peker, Department of General Surgery, Faculty of Medicine, Erzincan University, Erzincan, Turkey

Phone.: +90 4462122216 E-mail: k.peker@yahoo.com.tr hydatid disease. Each of the patients gave an informed consent for both treatment and publishing of data.

\section{CASE REPORTS}

\section{CASE 1 (Cystic Echinococcosis)}

A 56 year-old male patient with tenesmus, lower abdominal pain and progressive constipation continuing for one month, visited the outpatient clinic. His medical history was non-contributory except for weight loss of $9 \mathrm{~kg}$ over a three month period. Physical examination revealed abdominal tenderness. X-ray graphies were normal. The rectum was empty without any mass, on rectal examination. Abdominal ultrasonography (US) reported a $6 \times 7$ $\mathrm{cm}$ sized cystic lesion in the left lobe of the liver. In computed abdominal tomography (CAT) there was thickening in the rectal wall and perirectal fatty tissue was intact. There was a $62 \times 73 \mathrm{~mm}$ sized hydatid cyst in the left lobe of the liver, and no other additional pathology in the abdomen (Figure 1, 2).

There were no specific findings in the patient's history. Colonoscopy revealed a malignant-looking mass lesion $9 \mathrm{~cm}$ distant from the anal verge. Multiple biopsies were obtained. Histopathologic diagnosis of mass was adenocarcinoma. On admission, the blood pressure was $130 / 80 \mathrm{mmHg}$, body temperature was $36.4^{\circ} \mathrm{C}$, and the pulse was 84 per minute. In the abdominal area, mild tenderness was detected. In the general complete blood count, leukocytes were $5.800 / \mu \mathrm{L}$, hemoglobin was $15.6 \mathrm{~g} / \mathrm{dL}$, and platelets were 201.000/ $\mu \mathrm{L}$. In serology tests, HBs Ag was nega- 
tive, anti-HBs Ab was positive, anti- $\mathrm{HCV} \mathrm{Ab}$ was negative. The patient was advised to undergo rectum resection with concomittant hydatid cyst surgery, but theb patient did not give consent for hydatid cyst surgery. Rectal resection with colorectal anastomosis was performed on an elective basis. Definitive treatment for hydatid disease was postponed to further surgery.

\section{CASE 2 (Alveolar Echinococcosis)}

A 78 year-old male patient with abdominal pain and progressive constipation for five days was admitted to the emergency department. His medical history was non-contributory apart from a weight loss of $6 \mathrm{~kg}$ over a 3 month period. Physical examination revealed abdomen tenderness and rigidity. $\mathrm{X}$-ray graphies showed free air under the diaphragm. Ultrasonography revealed intra-abdominal free fluid. A mass was palpated on rectal examination. On admission, the blood pressure was $100 / 80 \mathrm{mmHg}$, the temperature was $37.8^{\circ} \mathrm{C}$, and the pulse was 86 per minute; the patient was conscious. No other special findings were detected. In the complete blood count, leukocytes were $13.400 / \mu \mathrm{L}$, hemoglobin was $11.7 \mathrm{~g} / \mathrm{dL}$, and platelets were 257.000/ $\mu \mathrm{L}$. In serology tests, $\mathrm{HBs} \mathrm{Ag}$ was negative, anti-HBs Ab was positive, anti- HCV

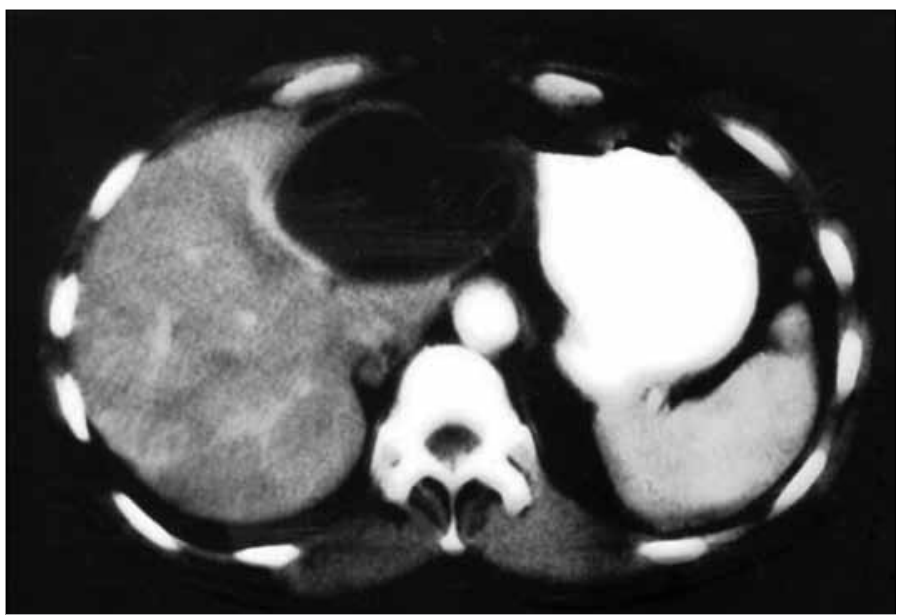

Figure 1. Contrast-enhanced tomographic image of hydatid disease filling the left lobe of liver

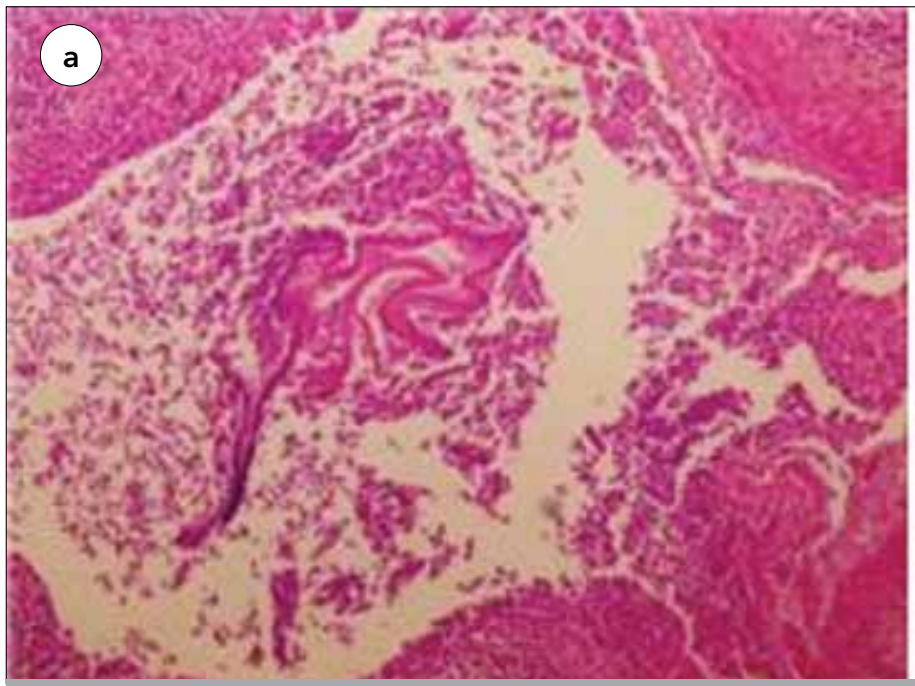

Ab was negative. The patient was operated on an emergency basis, a perforated rectum tumor with diffuse peritonitis was seen. The rectum was resected with Hartmann closure. In the perioperative exploration a mass was palpated on the right liver lobe. Biopsy was obtained on suspicion of liver metastasis. Histopathologic examination revealed alveolar hydatid disesase (Figure 3,4) On follow-up, abdominal tomography showed alveolar hydatid disesase in the right lobe of the liver.

\section{DISCUSSION}

Colorectal cancer (CRC) has been described as a disease of western populations but reports from the Asia-Pacific region also indicates increasing incidence of this malignity $(4,5)$. Environmental and genetic mechanisms have been implicated in the CRC pathogenesis (6).

E. granulosus occurs worldwide, and E. multilocularis is found in the Northern Hemisphere. Humans can develop the disease when they ingest eggs excreted with the feces of the final hosts (dogs and foxes). E. granulosus larvae then grow as large cysts with internal budding of brood capsules. E. multilocularis larvae

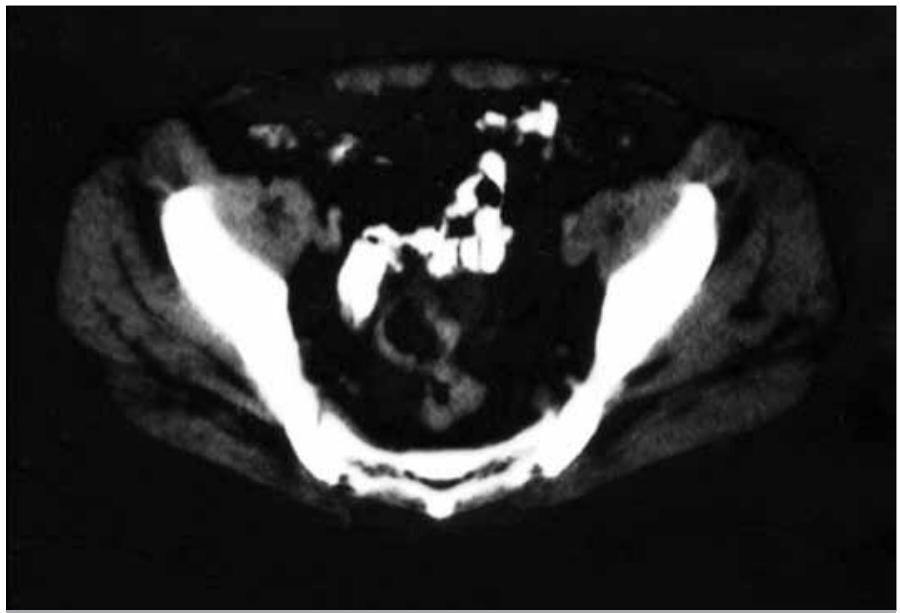

Figure 2. Tomographic image demonstrating rectal wall thickening in pelvic sections

Figure 3. a, b. Microscopic images of alveolar echinococcosis in liver parenchyma (hematoxylin\&eosin) 


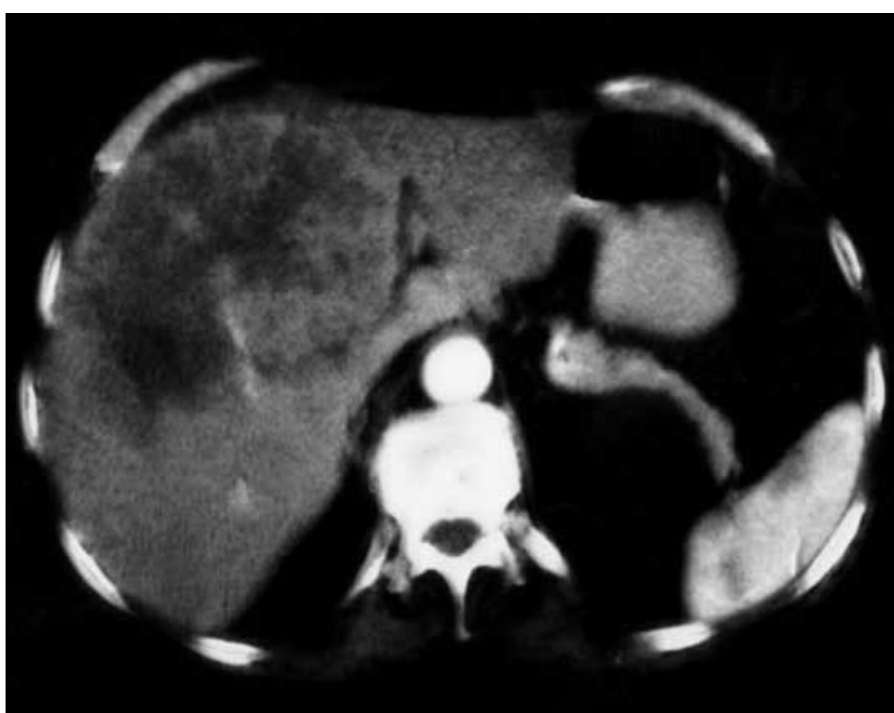

Figure 4. Tomographic image of alveolar echinococcosis in right lobe of liver

develops by external budding to form an infiltrative growing tumor (7).

Coexistence of hydatid disease with remote malignancies is rare. Lopez Martin et al. (8), reported a liver hydatid cyst which is defined with FDG-PET in a patient Duke's stage B rectal cancer. Gungor et al. (9), reported a concurrent borderline ovarian tumor and lymphoepithelioma-like gastric carcinoma in a patient with primary pelvic echinococcus. Moreover, association of echinococcal disease with liver hepatocellular carcinomas were reported in many studies (10). The simultaneous occurrence of echinococcosis and hepatocellular carcinoma is quite rare. Both of these diseases are chronic processes, and this further raises the possibility that echinococcosis could have a role in the development of the liver cancer (11).

Despite a relatively high incidence of both colorectal carcinomas and hydatid disease, there are very few reports of the coexistence of both diseases, in the literature $(8,12)$. It is possible to encounter hydatid disease in a patient who was operated for colorectal carcinoma. We could not perform simultaneous hydatid disease surgery since patient did not give consent in one case and for comorbidities and potential operative risks of the other patient. However; we think that it is reasonable to perform both colorectal and hydatid disease surgery simultaneously in an appropriate patient with low comorbidities, although there are no reported data in the literature.

\section{CONCLUSION}

Hydatid disease is a relatively frequent disease in eastern countries, especially in rural areas. As being the most common malignity of gastrointestinal tract, incidence of colorectal carcinomas is emerging in developing countries. Although simultaneous occurrence of echinococcosis disease and colorectal carcinoma is quite rare, it is possible to encounter coincidence of hydatid disease in a patient with colorectal malignity on an emergency or elective surgery basis. A careful preoperative evaluation may help to provide appropriate treatment for both diseases.
Conflict of Interest: No conflict of interest was declared by the authors.

Financial Disclosure: The authors declared that this case has received no financial support.

Peer-review: Externally peer-reviewed.

Informed Consent: Written informed consent was obtained from patients who participated in this case.

Author Contributions: Concept - K.P.; Design - K.P.; Supervision - K.P., A.I.; Funding - K.P.; Materials - K.P.; Data Collection and/or Processing K.P.; Analysis and/or Interpretation - K.P., A.I.; Literature Review - K.P., A.I.; Writing - K.P., A.I.; Critical Review - K.P., A.I.; Other - K.P., A.I.

Çıkar Çatışması: Yazarlar çıkar çatışması bildirmemişlerdir.

Finansal Destek: Yazarlar bu olgu için finansal destek almadıklarını beyan etmişlerdir.

Hakem değerlendirmesi: Dış bağımsız.

Hasta Onamı: Yazılı hasta onamı bu olguya katılan hastalardan alınmıştır.

Yazar Katkıları: Fikir - K.P.; Tasarım - K.P.; Denetleme - K.P., A.I.; Kaynaklar - K.P.; Malzemeler - K.P.; Veri toplanması ve/veya işlemesi - K.P.; Analiz ve/ veya yorum - K.P., A.I.; Literatür taraması - K.P., A.I.; Yazıyı yazan - K.P., A.I.; Eleştirel İnceleme - K.P., A.I.; Diğer - K.P., A.i.

\section{REFERENCES}

1. Kirkegaard H, Johnsen NF, Christensen J, Frederiksen K, Overvad $K$, Tjonneland A. Association of adherence to lifestyle recommendations and risk of colorectal cancer: a prospective Danish cohort study. BMJ 2010; 341: c5504. [CrossRef]

2. Russo CA, Stocks C. Hospitalizations for Colorectal Cancer, 2006: Statistical Brief \#69. Healthcare Cost and Utilization Project (HCUP) Statistical Briefs [Internet]. Rockville (MD): Agency for Health Care Policy and Research (US); 2006-2009.

3. Ito A, Urbani C, Jiamin Q, Vuitton DA, Dongchuan Q, Heath DD, et al. Control of echinococcosis and cysticercosis: a public health challenge to international cooperation in China. Acta Trop 2003; 86: 3-17. [CrossRef]

4. Bray F, Sankila R, Ferlay J, Parkin DM. Estimates of cancer incidence and mortality in Europe in 1995. Eur J Cancer 2002; 3 8: 99-166. [CrossRef]

5. Sung JJ, Lau JY, Goh KL, Leung WK; Asia Pacific Working Group on Colorectal Cancer. Increasing incidence of colorectal cancer in Asia: implications for screening. Lancet Oncol 2005; 6: 871-6. [CrossRef]

6. Dove-Edwin I, Thomas HJ. Review article: the prevention of colorectal cancer. Aliment Pharmacol Ther, 2001; 15: 323-36. [CrossRef]

7. Wen H, New RR, Craig PS. Diagnosis and treatment of human hydatidosis. Br. J. Clin. Pharmacol 1993; 35: 565-74. [CrossRef]

8. López Martín J, Borrego Dorado I, Santaella Guardiola Y, Vázquez Albertino R. Casual finding of a hepatic hydatid cyst with FDGPET in patient with rectal carcinoma, Rev Esp Med Nucl, 2004; 23 : 131-2. [CrossRef]

9. Gungor T, Altinkaya SO, Sirvan L, Lafuente RA, Ceylaner S. Coexistence of borderline ovarian epithelial tumor, primary pelvic hydatid cyst, and lymphoepithelioma-like gastric carcinoma. Taiwan J Obstet Gynecol 2011; 50: 201-4. [CrossRef]

10. Molina FX, Morón JM, de la Serna S, Martí-Corbella A, Soro JA. Intrahepatic cholangiocarcinoma on a hydatidic cyst. Cir Esp 2007; 82: 182-4.

11. Kostov D, Dragnev N, Patanov R, Kobakov G. Hepatocellular carcinoma complicated with echinococcal cyst of the liver. Khirurgiia (Sofiia) $2010:$ 49-50.

12. Koca G, Ilgan S, Kitapçı MT. Kolon kanserli bir olguda FDG PET görüntülemede metastazı taklit eden karaciğer kist hidatiği. Gulhane Med J 2012; 54: 243-7. 